\title{
Screening of indigenous active lactic acid bacteria isolated from freshly drawn raw milk
}

\author{
Selvajeyanthi $\mathrm{S}^{1}$ and Hemashenpagam $\mathrm{N}^{2}$ \\ ${ }^{1}$ Research Scholar, Department of Microbiology, Hindusthan College of Arts and Science \\ ${ }^{2}$ Professor, Department of Microbiology, Hindusthan College of Arts and Science, Coimbatore, Tamil Nadu
}

\begin{abstract}
Main emphasis of the present study was to isolate and identify active Lactic Acid Bacteria from various raw milk. Totally 36 freshly drawn various raw cow, buffalo, goat and sheep milk from Tirupur and Erode region in Tamil $\mathrm{Nadu}$, were collected. From the sample 56 Lactic Acid Bacteria (LAB) isolates were taken randomly. The LAB were phenotypically identified and grouped based on the morphological, physiological and biochemical study. The strain survival were also assessed under stomach acid condition like low $\mathrm{pH}$ and resistance to bile salt 0.3\%. Antibiotic sensitivity tests were performed for five antibiotics. After hemolytic activity on blood agar medium the antibacterial activities of the isolates were tested against two pathogenic bacteria E.coli and Staphylococcus $s p$., at pH 6.5 by overlay method. The tested isolates showed invitro inhibitory zone against pathogenic bacteria. From this study we can conclude that raw milk is good source of active lactic acid bacteria. Out of the 56 LAB isolates 28 exhibited good probiotic properties and potentiality was characterized in future.
\end{abstract}

KEY WORDS: RAW MILK, LACTIC ACID BACTERIA, PHENOTYPICAL IDENTIFICATION, ANTIBIOTIC SENSITIVITY, ANTIBACTERIAL ACTIVITY

\section{INTRODUCTION}

Ancient Indian has practice to consume freshly drawn raw milk without boiling. They believed that raw milk has some good property. Milk is an excellent medium to carry an active lactic acid bacteria and buffering capacity of milk helps to improve the survival of pro- biotic flora in the gastrointestinal tract, (Kailasapathy and Phillips 2008).Lactic acid bacteria tolerate high salt concentrations as its allows the bacteria to begin metabolism, which produces acid that further inhibits the growth of undesirable microorganisms (Pooja Thakkar et al., 2015). Probiotic LAB can be a suitable alternate of antimicrobial agents and recently found to play a

\section{ARTICLE INFORMATION:}

*Corresponding Author: selvajeyanthi@gmail.com Received $1^{\text {st }}$ Aug, 2018

Accepted after revision $29^{\text {th }}$ Sep, 2018

BBRC Print ISSN: 0974-6455

Online ISSN: 2321-4007 CODEN: USA BBRCBA

O\%: Thomson Reuters ISI ESC / Clarivate Analytics USA and

Crossref Indexed Journal

NAAS Journal Score 2018: 4.31 SJIF 2017: 4.196

- A Society of Science and Nature Publication, Bhopal India 2018. All rights reserved.

Online Contents Available at: http//www.bbrc.in/

DOI: $10.21786 / \mathrm{bbrc} / 11.3 / 11$ 
positive role in mental health. Milk is one of the natural habitats and rice source of LAB, (Delavenne et al., 2012, Wouters et al, 2002 and Misganaw wassie and Teketay wassie, 2016, Mokoena et al., 2016).

The LAB in milk and milk products enhance bioavailability of nutrients and act as a preservative(Misganaw wassie and Teketay wassie, 2016). Fermented and functional foods and the products are crucial to the human health(oktay Yerlikaya, 2014).Potential probiotic isolates of Lactobacillus rhamnosus and L. plantarum were present in indigenous goat milk (Setyawardani et al., 2011). The probiotic L.yoghurt supplementation to worldwide waterborne diarrhea causing Giardia infected mice reduced the severity of Giardia infection (Geeta shukla et al., 2010). Lactic acid bacteria produce antimicrobial compounds, vitamins or useful enzymes which could help in promotion of food industry (Ashmaig et al., 2009). Identify potent attributes to meet out current demands of the functional food industry (Subhashini, 2014).

\section{MATERIALS AND METHODS}

36 samples of raw fresh milks were collected from lactating cow, buffalo, goat and sheep in the rural area surrounding of Tirupur \& Erode District. Samples were collected using sterile centrifuge tubes and stored in an icebox until delivery of the laboratory for analysis. Till the analysis samples were kept in $4^{\circ} \mathrm{C}$ (refrigerator). About $1 \mathrm{ml}$ of milk sample was mixed with $9 \mathrm{ml}$ of saline $[8.5 \mathrm{~g} / \mathrm{L}]$ to make an initial dilution $\left[10^{-1}\right]$. The suspension was used for making suitable serial dilutions up to $10^{-8}$. Enumeration of LAB was determined using MRS (Man de Rogosa Sharpe) agar and M17 agar medium by pour plate [ $1 \mathrm{ml}$ in $15 \mathrm{ml}$ medium] incubated at $37{ }^{\circ} \mathrm{C}$ for 24-48 hours. After incubation colonies were chosen based on their morphology on MRS (pH-5.7) agar plate. The typical LAB were randomly picked up and purified for further work. Simple tests such as gram staining, catalase test, motility and sugar fermentation test were performed for isolates.

The isolates grown in freshly prepared liquid media and incubated overnight. After incubation the cells were taken and then gram staining procedure was performed. The gram reaction of the isolates was determined by light microscopy. Catalase enzyme produced by many microorganisms that breaks down the $\mathrm{H}_{2} \mathrm{O}_{2}$ into water and oxygen that releases $\mathrm{O}_{2}$ gas bubbles. The formation of gas bubbles indicates the presence of catalase enzyme.

$$
2 \mathrm{H}_{2} \mathrm{O}_{2} \rightarrow 2 \mathrm{H}_{2} \mathrm{O}+\mathrm{O}_{2} \uparrow
$$

The freshly grown liquid cultures were also used for catalase activity by dropping 3\% hydrogen peroxide solution onto $1 \mathrm{ml}$ of overnight cultures and their catalase activity was observed.

(Thakkar et al., 2015). MRS broth supplemented with different Sugars (glucose, lactose and maltose) and phenol red as $\mathrm{pH}$ indicator was inoculated with active cultures at $1 \%$, incubated at $37^{\circ} \mathrm{C}$ for 24 hours. The cultures were identified based on acid and gas production in Durham's tube after the incubation period. To check the growth of isolates at various $\mathrm{pH}$, MRS broth supplemented with different $\mathrm{pH}$ 2.0, 3.0, 7.0, 8.5 was prepared, $1 \%$ of fresh culture was inoculated and then incubated at $37^{\circ} \mathrm{C}$ for 28 hours. During incubation, extent of growth was recorded objectively based on visible turbidity marked as double positive sign $(++)$ for maximum growth, single positive sign (+) for normal growth and negative sign (-) for no growth. Turbidity also measured at 620nm.Overnight active cultures were inoculated at $1 \%$ in MRS broth tubes and incubated up to 7 days at 15, 37,45 and $55^{\circ} \mathrm{C}$. Extent of growth was visually recorded based on intensity of turbidity. Overnight grown active cultures were inoculated at $1 \%$ in MRS broth tubes adjusted to various concentrations of $\mathrm{Na} \mathrm{Cl}$ viz. 3.5, 6.5 and $18 \%(\mathrm{w} / \mathrm{v})$ along with their respective controls. The cultures were incubated at $37^{\circ} \mathrm{C}$. After 24 hours of incubation, extent of growth was recorded objectively based on visible turbidity marked as double positive sign $(++)$ for maximum growth, single positive sign (+) for normal growth and negative sign (-) for no growth.

Blood hemolysis test was carried out as per the method of Mabrouk et al.,( 2014). As the strains were isolated from food material, blood haemolysis test was performed, to eradicate any chance that our isolates may be pathogenic. It is also one of the criteria for assessing the safety of use of probiotics as food supplements. Pathogens produce highly toxic substance which lyse the RBC and forms a clear zone around them. The haemolytic activities of isolated strains were determined according to (Marakoudakis et al., 2009) as follows: all examined strains were grown in MRS broth at $37^{\circ} \mathrm{C}$ for 24 hours and then streaked onto Columbia agar base plates supplemented with $5 \%(\mathrm{v} / \mathrm{v})$ whole human blood. The plates were incubated at $37{ }^{\circ} \mathrm{C}$ for 48 hours. Then the clear zones and the color of haemolysis around the growth colonies were observed. Antibiotic susceptibility test was done using the method of Singh et al., (2014).

Probiotic strains must be sensitive to wards the antibiotics. There is a light risk that antibiotic resistance probiotic strain may transfer the antibiotic resistance genes to the pathogens via transformation in the gut. Due to any chance resistant pathogens get introduced into the human via food chain and cause serious problems. Sensitivity of probiotics strains towards the antibiotics being tested by using Kirby - Bauer disc diffusion technique. Tetracycline, Penicillin, Vancomycin, Strep- 
tomycin and Kanamycin was used. For this process MRS agar inoculated with $\mathrm{LAB}$ and disc were placed. After the incubation period ( 24 hours/ $37^{\circ} \mathrm{c}$ ) and inhibition zones were observed to determine the antibiotic resistance of isolates. Antagonistic activity was carried out by the method of (Bolanle et al., 2015).

The agar overlay method was employed to determine the ability of the viable lactic acid bacteria strains to inhibit the growth of the indicator pathogens, E.coli and Staphylococcus aureus. A loop full of LAB in MRS broth was inoculated on MRS agar plate as a thick line of about $2 \mathrm{~mm}$ and about $30 \mathrm{~mm}$ long at a good away from the edge of the plates and incubated under microaerophillic condition at $37^{\circ} \mathrm{C}$ for 24 hours. After incubation, the MRS agar plates were overlaid with approximately $0.2 \mathrm{ml} \times 10^{-7} \mathrm{CFU} / \mathrm{ml}$ of an overnight broth culture of the test pathogens inoculated in $10 \mathrm{ml}$ of Muller Hinton soft agar (with $0.7 \%$ agar-agar). The overlay was allowed to set and incubated at $37^{\circ} \mathrm{C}$ under aerobic condition. The plates were then examined for zone of inhibition around the line of the LAB and the clear zones were measured.

\section{RESULTS AND DISCUSSION}

A total of 56 LAB isolates were identified from various freshly drawn raw milk samples collected from surrounding of Tirupur and Erode district (Table 1).

All the fifty six isolates were gram positive, nonmotile in hanging drop method, fifty isolates were catalase negative and only six showed positive to catalase test were not a LAB. The cell morphology of fifty six isolates was evaluated through grams reaction microscopic observation and majority of 36 were found to be rods and the remaining of 20 isolates were cocci shaped. Among the isolates 42 were able to produce $\mathrm{CO}_{2}$ from glucose fermentation. This result showed that they were heterofermentative and remaining of 14 isolates were homofermentative. Homofermentative LAB utilize glucose via EMP pathway and heterofementors utilize via HMP (hexose monophosphate pathway) described by Rattanachaikunsopon and Phumkhachorn (2010). All the isolates grew at $37^{\circ} \mathrm{C}$ but only 21 isolates were grew at $15^{\circ} \mathrm{C}$; in $45^{\circ} \mathrm{C}$ and $55^{\circ} \mathrm{C}$, only ten isolates were showed limited growth. In $3.5 \% \mathrm{Na} \mathrm{Cl}$ concentration all the isolates grew well and only 27 showed growth at 6.5\% Na $\mathrm{Cl}$ concentration. 21 isolates showed limited growth at $18 \% \mathrm{Na} \mathrm{Cl}$ concentration.

Based on the morphological, physiological and biochemical test chemometric result hierarchical cluster analysis (AHC) for finding homogenous group of isolates and graphics were performed using XLStat software version 2018.5, Addinsoft. Dendrogram showing the similarity relationship among the 56 isolates of LAB obtained from various raw milk. Similarities were calculated by the simple matching coefficient and grouping was performed by Agglomeration hierarchical cluster (AHC) analysis using Un-weighted pair group average linkage analysis. A total of 56 isolates characterized using set of 17 phenotypic test. An abridged dendrogram depicting the similarity relationship among the isolates were divided into six groups shown in figure 2 . While the phenotypic characterization of the main clusters were summarized in linkage analysis figure 1.

Results showed that all the examined strains did not exhibited $\beta$ haemolysis and most of the strains were $\gamma$ haemolytic (non-pathogenic), while seven exhibited $\alpha$ haemolysis. Out of seven, five isolates were catalase positive there were not a LAB avoided of further work.Some of Enterococcus showed $\alpha$ haemolysis and as well as $\beta$ haemolysis summarized by W.Liu et al (2014). According to the European Food Safety Authority (2012) antibiotics of Tetracyclin, Streptomycin and Kanamycin were used for antibiotic suscebtibility testing of the isolated LAB.

\begin{tabular}{|l|l|l|l|l|l|}
\hline \multicolumn{2}{|c|}{ Table 1. Origin and designation of the isolates of Lactic acid bacteria } \\
\hline \multirow{2}{*}{ S. No } & & & No. of & \multirow{2}{*}{$\begin{array}{l}\text { No. of } \\
\text { isolates }\end{array}$} & \\
\cline { 2 - 3 } & Sample & Region & Designation of Strains \\
\hline 1 & College & Tirupur, Erode & 2 & 5 & C2, C9, C16, C7, C19 \\
\hline 2 & Sindhu & Tirupur, Erode & 11 & 11 & C3, C5, C11, C13, C14,C17, C18, C20, C21, C22, C23 \\
\hline 3 & Cooli & Tirupur, Erode & 2 & 5 & C1, C6, C8, C12, C24 \\
\hline 4 & Jersey & Tirupur, Erode & 1 & 3 & C4, C10, C15 \\
\hline 5 & Buffalo & Tirupur, Erode & 2 & 5 & B25, B26, B27, B28, B29 \\
\hline 6 & Goat (Black) & Tirupur, Erode & 4 & 8 & G4,G15,G16,G21,G25,G26,G27,G1 \\
\hline 7 & Goat (white) & Tirupur, Erode & 12 & 17 & $\begin{array}{l}\text { G2,G6,G13,G14,G5,G10, G7,G8,G12,G17,G9,G18, } \\
\text { G19,G20,G22,G23,G24 }\end{array}$ \\
\hline 8 & Sheep & Tirupur, Erode & 2 & 2 & S3,S11 \\
\hline
\end{tabular}




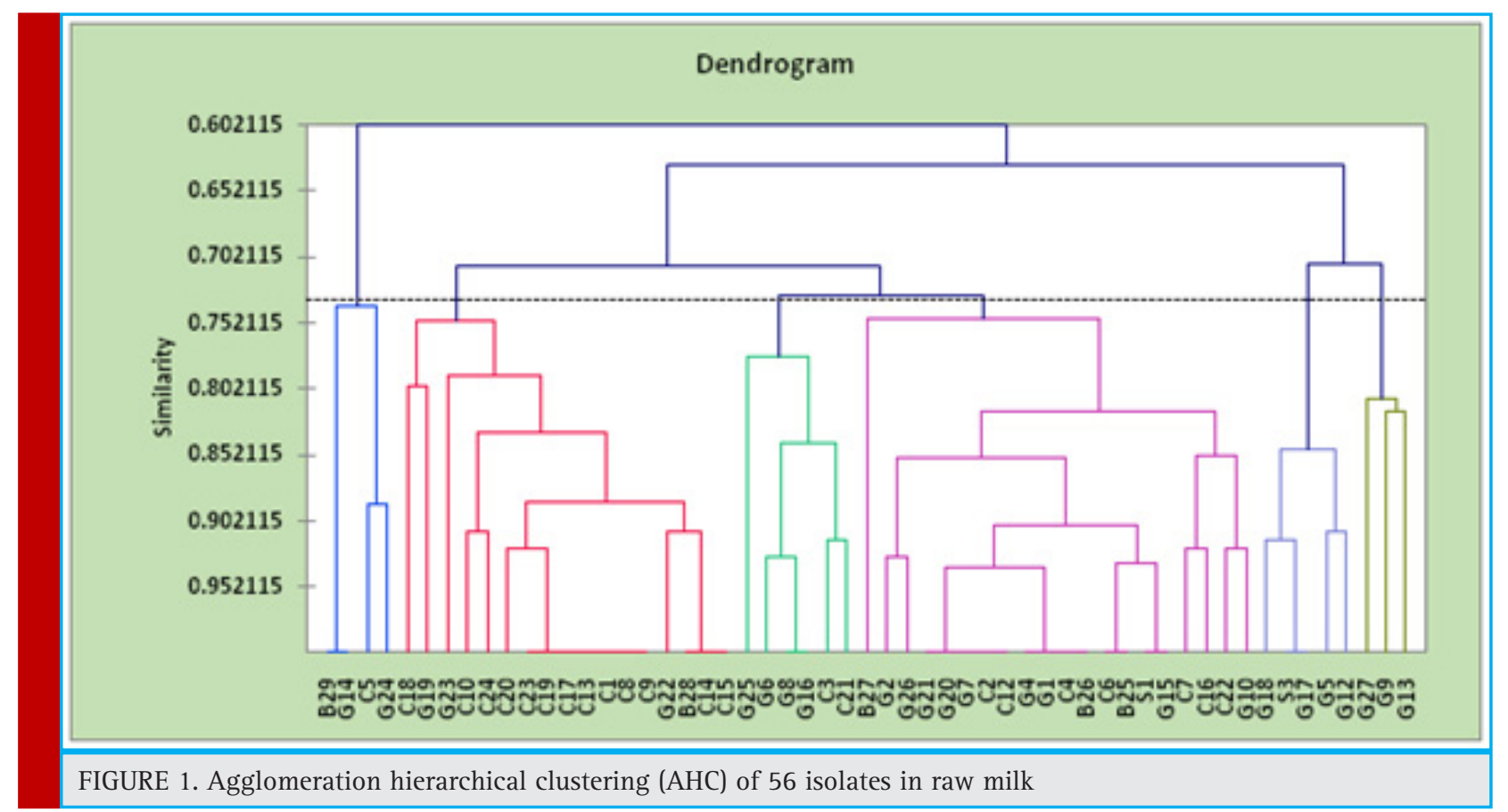

Results showed in figure 3 descripes 50\% of the isolates were resistant to antibiotics. A similar observation was given by Hawaz (2014) who also noticed Ethiopia curd had Lactobacillus and L. delbruekii, L.brevis and L. casei were resistance to antibiotic streptomycin and gentamycin; L. fermentum, L. lactis and L. rhamnosus were resistant to streptomycin. L. leichmanni, L. acidophillus and $L$. coagulants, which were only sensitive to antibi- otics. Furthermore Pundir et al (2013) had reported LAB isolates from food sample were found to be resistance to most of the antibiotics. Zarour et al (2012) had also reported goat and camel milk isolates were resistant to Vancomicin the strains had a poly resistance to antibiotics which is attributed to plasmid transposons in many bacterial strains. Based on the frequency of antibiotic sensitive isolates were taken for further analysis.

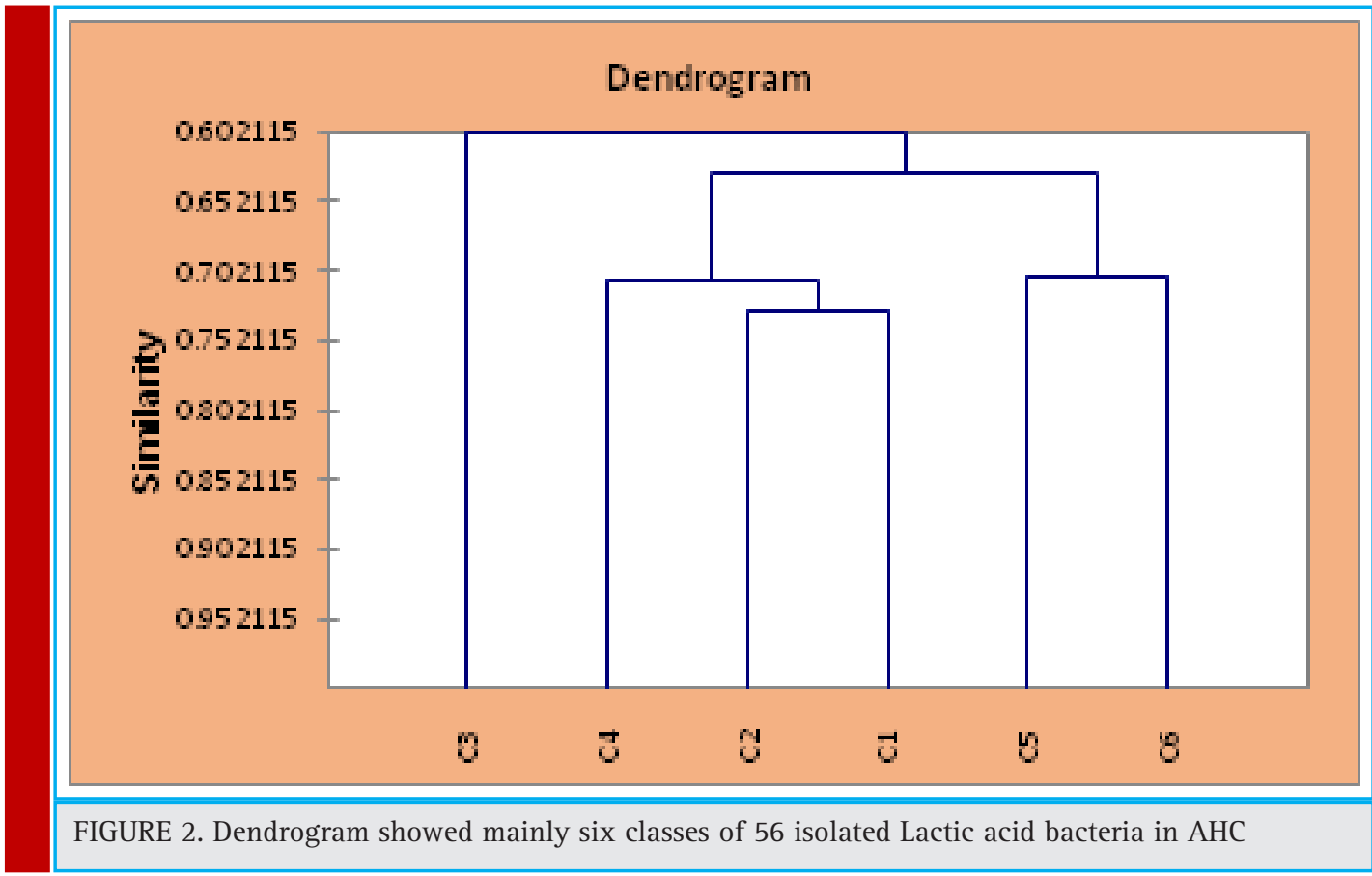




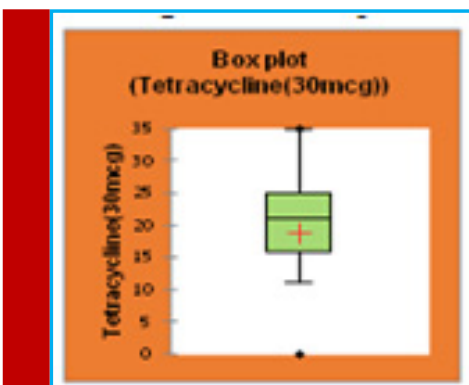

a) 10 resist anc e/56 isolates

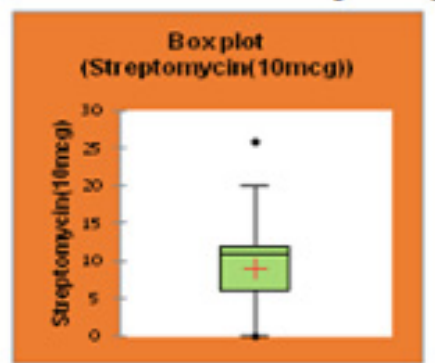

b)14 resistance /56 isolates

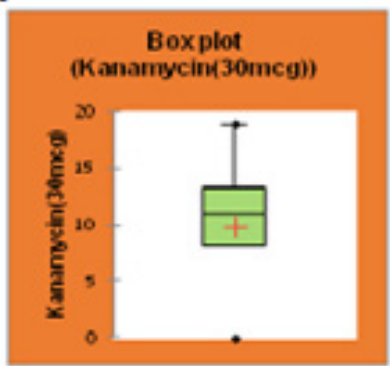

c)13 resistance/56 isolates

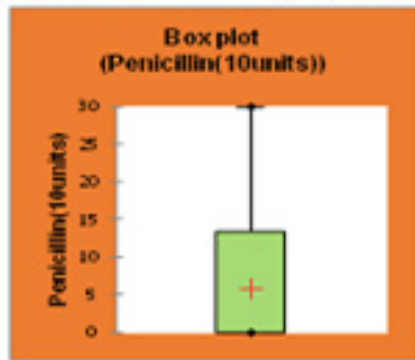

d) 35 resistance /56 isolates

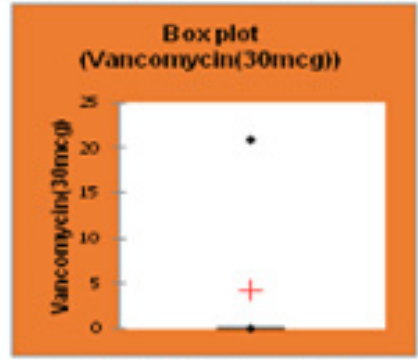

e) 44 resistance / 56 isolates

FIGURE 3. Descriptive statistics of Antibiotic susceptibility pattern of LAB isolates
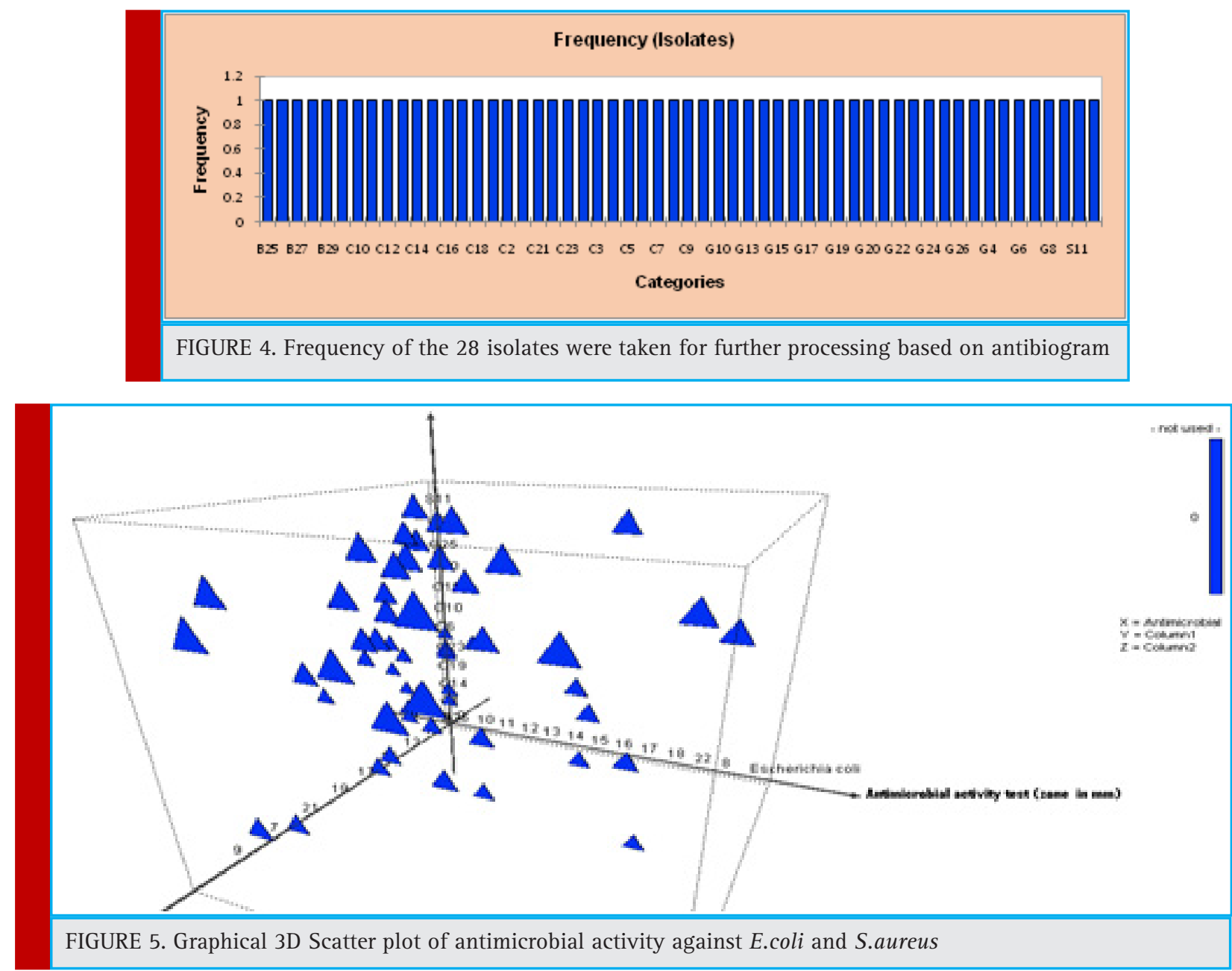

430 


\begin{tabular}{|c|c|c|c|c|c|c|c|c|c|c|c|}
\hline \multirow[t]{2}{*}{ S. No } & \multirow[t]{2}{*}{ Isolates } & \multicolumn{3}{|c|}{\begin{tabular}{|l}
$\begin{array}{l}\text { Blood } \\
\text { haemolysis } \\
\text { test }\end{array}$ \\
\end{tabular}} & \multicolumn{5}{|c|}{ Antibiotic susceptibility test (zone in $\mathrm{mm}$ ) } & \multicolumn{2}{|c|}{$\begin{array}{l}\text { Antimicrobial } \\
\text { activity test } \\
\text { (zone in } \mathrm{mm} \text { ) }\end{array}$} \\
\hline & & $\alpha$ & $\beta$ & $\gamma$ & $\begin{array}{l}\text { Tetracycline } \\
\text { (30 mcg) }\end{array}$ & $\begin{array}{l}\text { Penicillin } \\
\text { (10 units) }\end{array}$ & $\begin{array}{l}\text { Vancomycin } \\
\text { (30 mcg) }\end{array}$ & $\begin{array}{l}\text { Streptomycin } \\
\text { (10 mcg) }\end{array}$ & $\begin{array}{l}\text { Kanamycin } \\
(30 \mathrm{mcg})\end{array}$ & E. coli & S. aureus \\
\hline 1 & C1 & - & - & - & $\mathrm{R}$ & $\mathrm{R}$ & $\mathrm{R}$ & $\mathrm{R}$ & $\mathrm{R}$ & 22 & 19 \\
\hline 2 & $\mathrm{C} 2$ & - & - & - & 22 & $\mathrm{R}$ & $\mathrm{R}$ & 9 & 14 & - & 13 \\
\hline 3 & C3 & - & - & - & 25 & 10 & $\mathrm{R}$ & 12 & 12 & - & 14 \\
\hline 4 & C4 & + & - & - & 23 & $\mathrm{R}$ & $\mathrm{R}$ & 10 & \begin{tabular}{|l|}
8 \\
\end{tabular} & - & 19 \\
\hline 5 & C5 & - & - & - & $\mathrm{R}$ & $\mathrm{R}$ & $\mathrm{R}$ & $\mathrm{R}$ & $\mathrm{R}$ & - & 13 \\
\hline 6 & C6 & + & - & - & 15 & $\mathrm{R}$ & $\mathrm{R}$ & 10 & \begin{tabular}{|l|}
11 \\
\end{tabular} & - & - \\
\hline 7 & C7 & - & - & - & 29 & $\mathrm{R}$ & $\mathrm{R}$ & 12 & 11 & 11 & 11 \\
\hline 8 & C8 & - & - & - & 31 & $\mathrm{R}$ & $\mathrm{R}$ & 13 & 14 & - & 16 \\
\hline 9 & C9 & - & - & - & 23 & 9 & $\mathrm{R}$ & 12 & 12 & - & 14 \\
\hline 10 & C10 & - & - & - & $\mathrm{R}$ & $\mathrm{R}$ & $\mathrm{R}$ & $\mathrm{R}$ & $\mathrm{R}$ & 14 & 18 \\
\hline 11 & C11 & - & - & - & $\mathrm{R}$ & $\mathrm{R}$ & $\mathrm{R}$ & $\mathrm{R}$ & $\mathrm{R}$ & - & - \\
\hline 12 & C12 & - & - & - & 17 & 13 & 17 & 12 & 13 & 16 & 14 \\
\hline 13 & C13 & - & - & - & 22 & 20 & $\mathrm{R}$ & 11 & 12 & - & 13 \\
\hline 14 & C14 & - & - & - & $\mathrm{R}$ & $\mathrm{R}$ & $\mathrm{R}$ & $\mathrm{R}$ & $\mathrm{R}$ & - & - \\
\hline 15 & C15 & - & - & - & 31 & $\mathrm{R}$ & $\mathrm{R}$ & 12 & 12 & - & 13 \\
\hline 16 & C16 & + & - & - & 19 & $\mathrm{R}$ & $\mathrm{R}$ & 11 & 12 & - & 12 \\
\hline 17 & C17 & - & - & - & 22 & 15 & $\mathrm{R}$ & 11 & 11 & - & 12 \\
\hline 18 & C18 & - & - & - & 33 & $\mathrm{R}$ & $\mathrm{R}$ & 12 & 12 & 18 & 16 \\
\hline 19 & C19 & - & - & - & 32 & 10 & $\mathrm{R}$ & 16 & 15 & 14 & 21 \\
\hline 20 & C20 & - & - & - & 27 & 14 & $\mathrm{R}$ & 13 & 11 & 16 & 13 \\
\hline 21 & C21 & - & - & - & 22 & 13 & $\mathrm{R}$ & 10 & 11 & 14 & 18 \\
\hline 22 & C22 & - & - & - & 27 & 12 & $\mathrm{R}$ & 11 & 11 & 15 & 11 \\
\hline 23 & C23 & - & - & - & 32 & 21 & $\mathrm{R}$ & 26 & 11 & - & - \\
\hline 24 & C24 & - & - & - & 21 & 22 & 13 & 20 & 17 & - & - \\
\hline 25 & B25 & + & - & - & 18 & $\mathrm{R}$ & \begin{tabular}{|l|}
19 \\
\end{tabular} & 12 & 13 & - & 22 \\
\hline 26 & B26 & + & - & - & $\mathrm{R}$ & $\mathrm{R}$ & $\mathrm{R}$ & 8 & 10 & - & 16 \\
\hline 27 & B27 & + & - & - & 23 & $\mathrm{R}$ & $\mathrm{R}$ & 13 & 16 & - & 15 \\
\hline 28 & B28 & - & - & - & 21 & $\mathrm{R}$ & $\mathrm{R}$ & 10 & 11 & - & 11 \\
\hline 29 & B29 & - & - & - & 31 & $R$ & 21 & 11 & 12 & - & 8 \\
\hline 30 & G1 & - & - & - & $\mathrm{R}$ & $\mathrm{R}$ & $\mathrm{R}$ & $\mathrm{R}$ & $\mathrm{R}$ & - & 20 \\
\hline 31 & G2 & - & - & - & $\mathrm{R}$ & $\mathrm{R}$ & $\mathrm{R}$ & $\mathrm{R}$ & $\mathrm{R}$ & - & 14 \\
\hline 32 & S3 & - & - & - & 35 & 19 & 19 & 13 & 14 & 13 & 17 \\
\hline 33 & G4 & - & - & - & 22 & $\mathrm{R}$ & $R$ & 9 & 11 & - & 11 \\
\hline 34 & G5 & - & - & - & 34 & 14 & 20 & 15 & 18 & 10 & 9 \\
\hline 35 & G6 & - & + & - & 21 & $R$ & $R$ & 10 & 8 & - & 12 \\
\hline
\end{tabular}




\begin{tabular}{|c|c|c|c|c|c|c|c|c|c|c|c|}
\hline 36 & G7 & - & - & - & 21 & $\mathrm{R}$ & $\mathrm{R}$ & 15 & 16 & - & - \\
\hline 37 & G8 & - & - & - & 22 & $\mathrm{R}$ & $\mathrm{R}$ & 10 & 10 & 11 & 19 \\
\hline 38 & G9 & - & - & - & 17 & 16 & 16 & 13 & 14 & 16 & - \\
\hline 39 & G 10 & - & - & - & 16 & $\mathrm{R}$ & $\mathrm{R}$ & $\mathrm{R}$ & $\mathrm{R}$ & - & 15 \\
\hline 40 & S11 & - & - & - & 24 & $\mathrm{R}$ & $\mathrm{R}$ & $\mathrm{R}$ & 17 & - & 11 \\
\hline 41 & G12 & + & - & - & 30 & 14 & 16 & 11 & 12 & - & 16 \\
\hline 42 & G13 & - & - & - & 21 & 30 & 20 & 14 & 18 & 14 & 8 \\
\hline 43 & G14 & - & - & - & 30 & 17 & $\mathrm{R}$ & 13 & 13 & 13 & 15 \\
\hline 44 & G15 & - & - & - & 16 & $\mathrm{R}$ & 19 & 11 & 13 & 8 & 10 \\
\hline 45 & G16 & - & - & - & 22 & $\mathrm{R}$ & $\mathrm{R}$ & 11 & 11 & - & 14 \\
\hline 46 & G17 & - & - & - & 18 & 15 & 20 & 13 & 17 & 15 & 8 \\
\hline 47 & G18 & - & - & - & 14 & $\mathrm{R}$ & $\mathrm{R}$ & 11 & 12 & 12 & 7 \\
\hline 48 & G19 & - & - & - & 25 & 14 & $\mathrm{R}$ & $\mathrm{R}$ & 19 & 10 & - \\
\hline 49 & G20 & - & - & - & 17 & $\mathrm{R}$ & $\mathrm{R}$ & 12 & 14 & 17 & 20 \\
\hline 50 & G21 & - & - & - & 16 & $\mathrm{R}$ & $\mathrm{R}$ & $\mathrm{R}$ & $\mathrm{R}$ & - & 17 \\
\hline 51 & G22 & - & - & - & 24 & $\mathrm{R}$ & 20 & $\mathrm{R}$ & $\mathrm{R}$ & - & 9 \\
\hline 52 & G23 & - & - & - & $\mathrm{R}$ & $\mathrm{R}$ & $\mathrm{R}$ & $\mathrm{R}$ & $\mathrm{R}$ & - & - \\
\hline 53 & G24 & - & - & - & 21 & $\mathrm{R}$ & $\mathrm{R}$ & 11 & 10 & - & 13 \\
\hline 54 & G25 & - & - & - & $\mathrm{R}$ & $\mathrm{R}$ & $\mathrm{R}$ & $\mathrm{R}$ & $\mathrm{R}$ & - & 12 \\
\hline 55 & G26 & + & - & - & 11 & 10 & $\mathrm{R}$ & 10 & 11 & 14 & 22 \\
\hline
\end{tabular}

In this study, the antimicrobial activity showed 46 isolates produced maximum inhibition zone against bacterial pathogen Staphylococcus sp., comparatively less isolates of 22 produced zone against E.coli sp. Showed in figure 4. The present work contrary with Hawaz (2014) had reported Lactobacillus strains showed antibacterial effect against the pathogenic E.coli, Staphylococcus sp., and Salmonella thyphimurium. This may vary from type of strain and class of bacteriocin produced by LAB.

\section{CONCLUSION}

The present study concluded that freshly drawn animal milk had rich source of lactic acid bacteria and predominant $64 \%$ Lactobacillus sp. and 34\% of isolates were coccus that tentatively had Enterococcus, Leuconostoc, Streptococcus, Lactococcus and Pediococcus which is in conformity with earlier work. As raw milk is used more in Tamil Nadu being consumed frequently and occasionally, consumers received significant amount of LAB. Potentialities of probiotic characteristics are being done in further studies. Indeed, a natural preservation of characterized LAB in under investigation. Further work is required on species level identification of isolates and bioactive compounds produced by LAB.

\section{ACKNOWLEDGEMENT}

This work was carried out in AWECARE laboratory, Erode TN and supported by Dept. of Microbiology Tiruppur Kumaran College for Women and Hindusthan College. The support of Muthuselvi and Mehala helped in getting samples is heart fully acknowledged.

\section{REFERENCES}

Ahmed M.M. Mabrouk, Baher A.M. Effat, Zainab I.M. Sadek, N.F. Tawfiek, Z.M.R. Hassan and Mohamed N.I. Magdoub (2014) Antimicrobial activity of some Lactic acid bacteria Isolated from Egyptian Dairy Products, International Journal of Chem Tech Research CODEN (USA) Vol.6, No.2, pp 1139-1150

Ashwani Kumar Singh, Abhishek Pandey, Megha Sharma, Komudi and Anupam Singh (2014) "Probiotic activities of lactic acid bacteria isolated from human breast milk, Journal of Biological Engineering Research and Review., Vol.1, Issue 2, 07-12, www.biologicalengineering.in

Ayman Ashmaig, Alaa Hasan and Eisa El Gaali (2009) Identification of lactic acid bacteria Isolated from traditional Sudanese fermented camel's milk, African journal of Microbiology Research Vol.3 (8) pp. 451-457 http://www.academicjournals. org/ajmr

Bolanle A. Adeniyi, Adewale Adetoye, Funmilola A (2015) Ayeni Antimicrobial activities of lactic acid bacteria isolated 
from cow faeces against potential enteric pathogens, African health sciences, Vol 15 issue 3: 888-895.

Delavenne. E, J. Mounier, F. Déniel, G. Barbier and G. Le Blay (2012) Biodiversity of Antifungal Lactic Acid Bacteria Isolated from Raw Milk Samples from Cow, Ewe and Goat over OneYear Period, International Journal of Food Microbiology, Vol. 155, No. 3, pp. 185-190.

European Food Saftey Authority (EFSA) - committed since 2002 to ensuring that Europe's food is safe: http://www.efsa. europa.eu/ en/search.htm?text=probiotics8p=10]

Geeta Shukla, Gatha Sharma and Nisha Goyal (2010) Probiotic characterization of Lactobacilli and yeast strains isolated from Whey beverage and Therapeutic potential of Lactobacillus yoghurt in Murine Giardiasis, American journal of biomedical sciences vol-2(3): 248-261.

Hawaz E (2014) Isolation and identification of probiotic lactic acid bacteria from curd and in vitro evaluation of its growth inhibition activities against pathogenic bacteria, African Journal of Microbiology Research vol. 8 (13), pp. 1419-1425, DOI:10.5897/AJMR14.6639 http://www.academicjournals.org/ AJMR, Article No. D80ED0B46925

Kailasapathy K, Phillips H M (2008) Survival of lactobacillus acidophilus and Bifidobacterium animalis sp., lactis is stirred fruit yougurts. LWT-Food Science Technology; Vol. 41,1317-1322

Liu, W H. Zhang and H. Pang, Y. Cai, Lactic acid bacteria, Chapter 2 Biodiversity of Lactic acid bacteria, ${ }^{\circ}$ Springer Science + Business Media Dordrecht 2014, DOI:10.1007/978-940178841-0 2

Marakoudakis P.A.M Papadelli, M Georgalaki, E G Panayotopoulou, B M Gonzalez, A.F. Mentis, K. Petraki, DS Sgouras and E Tsakalidou (2009) In vitro and in vivo safety evaluation of bacteria in producer, Streptococcus macedonicus ACA-DC198. International Journal of Food Microbiology, 133:141-147

Mduduzi Paul Mokoena,Taurai Mutanda and Ademola 0. Olaniran (2016) "Review Article-Prospectives on the probiotic potential of lactic acid bacteria from African traditional fermented foods and beverages, Food and Nutrition research, 60;29630-http//dx.doi.org/10.3402fnnv60.29630
Oktay Yerlikaya (2014) Starter cultures used in probiotic dairy drinks, Food Science and Technology, campinas, 34(2):221-229 DOI:http://dx.doi.org/10.1590/fst2014-0050

Pooja Thakkar, H.A. Modi and J.B. Prajapati (2015) "Isolation, characterization and safety assessment of lactic acid bacteria isolate from fermented food products," Int. J. curr. Microbiol. App. Sci; 4(4); 713-725

Rattanachaikunsopon P and P. Phumkhachorn (2010) "Lactic acid bacteria: their antimicrobial compounds and their uses in food production," Annals of Biological Research,1(4): 218-228 www.scholarsresearchlibrary.com

Ram Kumar Pundir, Satish Rana, Neha Kashyap and Amandeep kaur (2013) Probiotic potential of lactic acid bacteria isolated from food samples:an in vitro study, Journal of Applied Pharmaceutical Science vol. 3 (03), pp. 085-093, DOI:10.7324/ JAPS.2013.30317 http://www.japsonline.com

Subhashini (2014) Bioprospecting of LAB for potentiality as probiotics International Journal of Microbiological Research 5(2); 90-97 DOIL:10.5829/idosi.ijmr.2014.5.2.83291

Setyawardani T et al. (2011) Potential probiotic isolates of Lactobacillus rhamnosus and L.plantarum were present in indigenous goat milk, Animal Production13(1):55-63 http://ww w. researchgate.net/publication/228472966

Wassie Misganaw and Wassie Teketay (2016) Isolation and identification of Lactic acid bacteria from Raw cow milk, International journal of Advanced research in Biological Sciences vol. 3(8) pp. 44-49

Wouters J.T, Ayad E.H, Hugenholtz J, Smit G (2002) Microbes from raw Milk for Fermented Dairy Products, International Dairy Journal: Vol.12 No.2-3., pp.91-109

Zarour K, Benmechernene Z, Hadadji M,Moussa-Boudjemaa B, Henni D.J and Kihal M (2012) Bioprospecting of Leuconostoc mesenteroids strains isolated from Algerian raw camel and goat milk for technological properties useful as adjunct starters, African Journal of Microbiology Research vol. 6(13), pp. 3192-3201, DOI:10.5897/AJMR11.1542 http://www.academicjournals.org/AJMR 